\title{
The ADRIREEF database: a comprehensive collection of natural/artificial reefs and wrecks in the Adriatic Sea
}

\author{
Annalisa Minelli ${ }^{1}$, Carmen Ferrà ${ }^{1}$, Alessandra Spagnolo ${ }^{1}$, Martina Scanu ${ }^{1}$, Anna Nora Tassetti ${ }^{1}$, \\ Carla Rita Ferrari ${ }^{2}$, Cristina Mazziotti ${ }^{2}$, Silvia Pigozzi ${ }^{2}$, Zrinka Jakl $^{3}$, Tena Šarčević ${ }^{3}$, Miranda Šimac ${ }^{3}$, \\ Claudia Kruschel $^{4}$, Dubravko Pejdo ${ }^{4}$, Enrico Barbone ${ }^{5}$, Michele De Gioia ${ }^{5}$, Diego Borme ${ }^{6}$, \\ Emiliano Gordini ${ }^{6}$, Rocco Auriemma ${ }^{6}$, Ivo Benzon ${ }^{7}$, Đeni Vuković-Stanišić ${ }^{7}$, Sandi Orlic ${ }^{8}$, \\ Vlado Frančić ${ }^{9}$, Damir Zec ${ }^{9}$, Ivana Orlić Kapović ${ }^{9}$, Michela Soldati ${ }^{10}$, Silvia Ulazzi ${ }^{10}$, and Gianna Fabi ${ }^{1}$ \\ ${ }^{1}$ National Research Council - Institute of Marine Biological Resources and Biotechnologies \\ - CNR IRBIM, Largo Fiera della Pesca 1, 60125 Ancona, Italy \\ ${ }^{2}$ ARPAE (Regional Agency for Prevention, Environment And Energy In Emilia Romagna), \\ Via Po 5, 40139 Bologna, Italy \\ ${ }^{3}$ SUNCE (Association for Nature, Environment and Sustainable Development), \\ Obala Hrvatskog Narodnog Preporoda 7/III, 21000, Split, Croatia \\ ${ }^{4}$ University of Zadar, Mihovila Pavlinovica 1, 23000 Zadar, Croatia \\ ${ }^{5}$ ARPA Puglia (Regional Agency for Environmental Prevention and Protection of the Puglia Region), \\ Corso Trieste 27, 70126 Bari, Italy \\ ${ }^{6}$ National Institute of Oceanography and Applied Geophysics - OGS, \\ Borgo Grotta Gigante 42/C, 34010 Sgonico, Italy \\ ${ }^{7}$ RERA (Public Institution RERA SD for Coordination and Development of Split Dalmatia County), \\ Domovinskog Rata 2, 21000 Split, Croatia \\ ${ }^{8}$ Ruđer Bošković Institute, Bijenicka 54, 10000 Zagreb, Croatia \\ ${ }^{9}$ Faculty of Maritime Studies, University of Rijeka, Studentska 2, 51000 Rijeka, Croatia \\ ${ }^{10}$ Municipality of Ravenna, Piazza del Popolo 1, 48121, Ravenna, Italy \\ Correspondence: Carmen Ferrà (carmen.ferravega@ cnr.it)
}

Received: 10 December 2020 - Discussion started: 29 December 2020

Revised: 9 March 2021 - Accepted: 31 March 2021 - Published: 7 May 2021

\begin{abstract}
The paper presents a database of information on wrecks, natural and artificial reefs located in the Adriatic Sea, collected within the framework of the Interreg Italy-Croatia project ADRIREEF - Innovative exploitation of Adriatic Reefs in order to strengthen Blue Economy. The data collection lasted more than 1 year and included three surveys and a wide literature review. After being collected, data were harmonized and, where possible, made machine-readable. Moreover, data were widely metadated, published in a WebGIS (https://adrireef.github.io/sandbox3/, last access: 3 May 2021), and shared as open data in EMODnet (European Marine Observation and Data Network) Data Ingestion Portal through the SEANOE repository (Ferrà et al., 2020; https://doi.org/10.17882/74880). The database is composed of 285 three-dimensional records, each one described by 51 attributes. Parameters are clustered in four main groups: identification, reef description, site description, and management/exploitation information. Available literature (scientific and/or grey) was also included in the database and linked to the corresponding site.
\end{abstract}




\section{Introduction}

In the Blue Innovation concept, the attractiveness and possible use of existing marine resources which are not yet properly exploited is relevant to promote sustainable economic development (Vogt, 1998; Orams, 2002; Cater and Cater, 2007; Kiper, 2013; Sakellariadou and Kostopoulou, 2015; Nurhayati et al., 2019) and redefine marine fisheries (Pauly, 2018; Stead, 2018). In this context, the recognition of less known and appreciated natural reefs (NRs), existing artificial structures (e.g. artificial reefs, rig-to-reefs; ARs), and wrecks could also be a successful way to pursue Blue Growth as all these sites might be suitable places for developing or improving sustainable activities such as fishing (both recreational and professional), nautical tourism, diving, and aquaculture (Wilhelmsson et al., 1998; Stolk et al., 2007; Uyarra et al., 2009; Needham, 2010; Edney, 2011; Spalding et al., 2017; Alempijević and Kovačić, 2019). Therefore, qualitative and quantitative information about the heritage presence and already existing human activities is fundamental to pursue an ecosystem-based sea use management according to the Maritime Spatial Planning (MSP) Directive (EU Directive 2014/89/EU, 2014; Douvere, 2008; Gilliland and Laffoley, 2008). As MSP is based on the three pillars for sustainable development - social, economic, and environmental its implementation will in turn facilitate the enforcement of the Marine Strategy Framework Directive (MSFD, European Commission, 2008) and the achievement of Good Environmental Status (GES).

This work represents the joint effort of Italian and Croatian partners participating in the Interreg Italy-Croatia project ADRIREEF (Innovative exploitation of Adriatic Reefs in order to strengthen blue economy, https://www.italy-croatia. eu/web/adrireef, last access: 3 May 2021) aimed at assessing the potentiality of reefs in the Adriatic Sea, in order to strengthen the Blue Economy. Within the framework of the project, natural reefs are defined as either biogenic or geogenic formations protruding from the solid or soft seabed with distinctive living marine resources. An artificial reef is a submerged natural or manmade structure deliberately constructed or placed on the seabed to emulate some functions of a natural reef such as protecting, regenerating, concentrating, and/or enhancing populations of living marine resources, while doing "no harm". Accidentally sunken ships and planes are instead defined as wrecks.

Based on the above considerations, this paper presents a comprehensive collection of 285 natural reefs, artificial reefs, and wrecks located in the Adriatic Sea within Italian, Croatian, and international waters.

An analogous attempt of inventory was made on intentionally sunk shipwrecks to serve as ARs over six continents (Ilieva et al., 2019). Anyway, no structures of this type were signalled in the Adriatic Sea, whereas available literature (Pivetta and Spazzapan, 2012) and our search highlighted the occurrence of several accidentally sunken ships which, any- way, act as artificial habitats. Similar attempts to geolocalize ARs and wrecks were made along the national coasts and offshore waters of Florida and Alabama (USA), by querying municipalities about the deployment of the reefs (US Fish and Wildlife Service, Wildlife \& Sport Fish Restoration Program, https://www.fws.gov/wsfrprograms/, last access: 3 May 2021), as well as in the Gulf of Mexico (Alabama Marine Resources Division, https://www.outdooralabama.com/ saltwater-fishing/artificial-reefs, last access: 3 May 2021). The latter dataset reports all the submerged structures (including ARs, rig-to-reefs, and wrecks) in the Gulf of Mexico, but only name, type of reef, and coordinates are publicly available. Lastly, some efforts were made concerning NRs within the ReefBase project (http://www.reefbase.org/ projects_partners/projects.aspx, last access: 3 May 2021), which helped localize and concisely qualify $\sim 10000$ reefs on a global scale (Oliver et al., 2002).

Another attempt made to identify aquaculture zones in the Adriatic Sea, also through a WebGIS application (http: //www.caps2.eu/caps2/, last access: 3 May 2021), reports zones of production, harvesting, and farms (Tora et al., 2017), but it does not include a few Italian reefs dedicated to this practice.

The collection work presented here is thus an ambitious attempt to gather in a single dataset the location, geometries, history, and detailed characteristics of natural reefs, artificial reefs, and wrecks existing in the Adriatic Sea. It required a deep knowledge on the overall status of the sites, their history, past and ongoing research and monitoring programmes carried out to characterize their ecological features, and on their current exploitation level. In this perspective, a key exercise in the ADRIREEF project was to obtain a classification of NRs, ARs, and wrecks occurring in the cooperation area and to provide a map of these sites from different perspectives: from the environmental to the economic point of view.

The result is an interactive map and an open-access detailed dataset (Ferrà et al., 2020) published on SEANOE whose contents are available for any user and purpose.

\section{Data mining}

Starting from an existing database, established in 2009 within the Italian Artificial Habitat Group of the Italian Society of Marine Biology (Fabi et al., 2011, 2015; http://www. habitatartificiali.irbim.cnr.it/wp, last access: 3 May 2021) carrying basic information about location and description of the artificial reefs, the National Research Council - Institute of Marine Biological Resources and Biotechnologies (CNR-IRBIM, http://www.irbim.cnr.it/it/index.php, last access: 3 May 2021) coordinated the data collection activity to improve it by developing and sharing among the ADRIREEF partners three online questionnaires on NRs, ARs, and wrecks (Appendices A, B, and C, respectively). 
An initial review of available literature and data was carried out to identify the necessary information on NRs and ARs and wrecks to be required. The questionnaires were structured in such a way to obtain a unique database for the two reef typologies and wrecks, including physical, ecological, and economic aspects, and allowing the classification of elements according to their characteristics. Given the importance of collecting answers quickly and having a structured and homogeneous database, it became essential to use easy online tools and to limit the possibility of free answers by proposing multiple-response questions (e.g. Google Forms application; https://www.google.com/forms/about/, last access: 3 May 2021).

The collected information was used to create the final ADRIREEF database which fed, in turn, a WebGIS application allowing the visualization of reefs and wrecks on an interactive map and their selection basing on running queries.

Projects' partners (PPs) were surveyed and answers were harmonized to obtain a consistent database. New features were defined and used as categories for the elements' classification and/or for the WebGIS application. Finally, all data properly checked and harmonized were assembled and used to populate the database.

\subsection{Literature and data review}

The review of existing literature took into account European environmental databases (https://www.eea.europa.eu/ data-and-maps, last access: 3 May 2021, https://ec.europa. eu/environment/nature/natura2000/data/index_en.htm, last access: 3 May 2021), research projects carried out by CNR-IRBIM and other entities, scientific publications, and grey literature. Based on the results of the review and expert knowledge, existing gaps in the information of already known reef sites and wrecks were identified.

With regard to ARs, a large part of inputs came from the abovementioned CNR-IRBIM database on artificial habitats in Italy, containing more than 500 bibliographic references and information on 80 Italian artificial habitats such as harbours, breakwaters, fish aggregating devices (FADs), offshore platforms, and ARs since 1967. By checking this database, it was possible to obtain a list of 150 studies regarding the Adriatic ARs published between 1977 and 2017. Conversely, a similar literature heritage was not present for NRs and wrecks.

\subsection{Questionnaire design}

The analysis of the collected information highlighted the need of improving existing data, especially on NRs and wrecks.

As ARs and NRs have completely different features, it was decided to develop two distinct questionnaires. A third questionnaire was developed for wrecks as they have peculiar characteristics. All questionnaires were built in a systematic way with the aims of (i) investigating the reefs' and wrecks' suitability for Blue Economy purposes and identifying those answers that would help to achieve this target and (ii) facilitating experts' participation in the poll by ordering questions into a logical structure.

The identification of the person(s) filling in the questionnaires was considered relevant to collect consistent information and have a contact person in case of missing data. Moreover, numerical information (distances, measures, coordinates) were asked in specific measurement units to add collected data directly to the database and avoid transformations.

\subsubsection{Identification of required information}

\section{Natural and artificial reefs}

Questions about reefs' characteristics that could influence their suitability for sustainable exploitation were divided into four main groups.

1. What is the reef and where is it located?

As a baseline, data regarding the identification of a reef are needed; therefore name and location (in the WGS84 coordinate reference system and decimal degrees) of the reef were required.

2. What are the main characteristics of the area where the reef is located?

The environmental characteristics of the area where a reef is located may influence its possible exploitation as well as its attractiveness to perform some activities; hence the following features were considered: minimum distance to the coast $(\mathrm{km})$; typology of the surrounding seabed; presence of meadows; important biocoenoses, alien, and protected species (in case of NRs); and possible protection level applied to the area (in case of NRs).

3. What are the physical features of the reef?

The reef's physical features may also influence its potential use, especially for ARs, which are hand constructed and designed for specific scopes. To answer this fundamental question, multiple characteristics are needed: the typology of the reef, reef bottom depth (m), reef edge (in metres, for NRs), spatial extension of the reef $\left(\mathrm{m}^{2}\right)$, the origin of the reef (for NRs, if biogenic or geogenic), the material used for the reef construction (for ARs), and structural design of the reef (for ARs, where it is necessary to know the type and number of modules/structures put in place and their layout).

4. Is the reef already managed and/or exploited and/or could it be the seat of new activities?

The actual use of a reef and/or the scope for which it was built, in the case of ARs, can limit the development of further activities; thus such information is crucial to 
identify possible synergies and conflicts with additional potential users. At the same time, the original purpose of an artificial reef turns out to be key information for better understanding monitoring and surveillance programmes, management plans, and possible grants taking place in the area, as those could also limit or benefit future uses. Therefore, the following information was requested: scope(s) for which an AR was built; whether the reef is managed (for both NRs and ARs) and, if yes, who is the management entity; whether a monitoring programme is already in place (for both NRs and ARs) and, if yes, its duration and the investigations carried out; and whether the reef area is subjected to grant or surveillance service (only for ARs). Furthermore, questions regarding available data (scientific publications, grey literature, monitoring data) were added to the questionnaires, as they could help for future research purposes.

\section{Wrecks}

The questionnaire related to the category of wrecks required some information shared with reefs and some extra information about the physical features of structure.

Shared information concerns (i) wreck identification (location and name), (ii) characterization of the surrounding area (distance from the coast, type of surrounding seabed, presence of meadows), (iii) physical features of the wreck (material, bottom depth, and wreck edge), and (iv) exploitation and protection of the wreck (exploitation, protection, and management of the site, if existing).

Extra information requested from the partners included weight of the wreck (tonnes), total area of the footprint $\left(\mathrm{m}^{2}\right)$, total volume of the shipwreck $\left(\mathrm{m}^{3}\right)$ and known dimensions (length, width, height in metres).

\subsection{Harmonization and construction of the database}

Firstly, all data collected from 270 questionnaires were screened to delete duplicates and identify incomplete entries and missing information, in order to make possible an evaluation of a reef/wreck for Blue Economy purposes. For these missing records, a data integration was requested from the contact person.

Data collected from questionnaires were then assembled together with those already contained in the CNR-IRBIM database and harmonized, as some answers were not in line with the requirements. Moreover, geolocations of reefs were inspected in a GIS environment, and, when those were inconsistent, clarifications were requested.

Once data control and harmonization were completed, a preliminary analysis and classification of the Adriatic reefswrecks were performed, and query filters of the WebGIS application were identified. Once criteria for reef/wreck classification and filters to be applied in the WebGIS applica- tion were definitely agreed upon with PPs, the ADRIREEF database was finalized.

The final database counted 51 columns, 48 of them derived by the questionnaires and 3 created by the database manager (type of reef, country, region). Of these fields, 10 were used as filters in the WebGIS application and/or for the reefs' classification, while the remaining 41 were used as part of technical information sheets.

\section{Database structure and geographical coverage}

The database counts 285 three-dimensional elements (latitude-longitude coordinate and bottom depth), described by 51 parameters and divided into 129 natural reefs, 47 artificial reefs, and 109 wrecks located in the Adriatic Sea falling into Italian, Croatian, and international waters (Table 1).

All artificial reefs and most wrecks fell within the Italian territorial waters, while the majority $(79 \%)$ of natural reefs were located within the Croatian ones. The presence of almost all the natural reefs on the eastern side of the studied area is mainly due to the geological morphology of the Adriatic basin (Stefanon, 1972), while the complete absence of artificial reefs on the same side is currently due to Croatian legal constraints. It is worth noting that the number of wrecks reported in the Croatian waters is somewhat underestimated. This fact is due to the lack of basic information about several wrecks (e.g. lack of exact position of the shipwreck, which did not allow placing it on the map), so it was decided to keep only those with adequately detailed information in the database. It is also worth noting that, given the great occurrence of rocky substrates along the Croatian coast, it was agreed within the ADRIREEF Consortium to identify homogeneous areas and map each of them as a single natural reef (Zec et al., 2019).

Location of reefs and wrecks is expressed in decimal degrees and the coordinate reference system WGS84. The database is available as a unique comma-separated value (CSV) file.

Table 2 summarizes the structure of the ADRIREEF database specifying the parameters required for each new element: parameter name, description, unit of measure, origin of the data (if they come directly from questionnaires or have been created by the database manager), and possible applicability restrictions. Table 2 also reports, for each parameter, the group it belongs to. As mentioned in Sect. 2.2.1, Group no. 1 corresponds to reef identification and geolocation information, Group no. 2 contains parameters summarizing the characteristics of the area hosting the reef or wreck, Group no. 3 concerns aspects of the reef/wreck that may also have an effect on its usage, and Group no. 4 includes parameters about the present and/or possible future reef or wreck exploitation. 
Table 1. Adriatic reefs and wrecks by typology and country.

\begin{tabular}{lrrrr}
\hline & Croatian waters & Italian waters & International waters & Total \\
\hline Artificial reefs & - & 47 & - & 47 \\
Natural reefs & 102 & 27 & - & 129 \\
Wrecks & 9 & 87 & 13 & 109 \\
\hline Total & 111 & 161 & 13 & 285 \\
\hline
\end{tabular}

\section{Data interrogation and visualization}

With the purpose of easily exploiting, representing, and filtering data, a WebGIS was created enabling the contemporary filtering (where applicable) of more than one of the following selected attributes:

- type of element,

- country,

- minimum depth of the reef/wreck,

- distance from the coastline,

- usage of the reef/wreck,

- reef typology (for natural reefs),

- reef material (for artificial reefs).

The WebGIS main page is reachable at the following URL: https://adrireef.github.io/sandbox3/ (last access: 3 May 2021), and it is composed of two user-friendly windows (Fig. 1), one reporting all available data filters (left side) and the other one (right side) showing the map where points, identifying elements, are divided by colour in NRs (green), ARs (blue), and wrecks (red). Hovering on an element with the mouse, its name and location appear in the left bottom corner of the map.

The total number of currently visualized elements is reported at the top right of the map. Moreover, when an element is clicked, a pop-up window appears showing the associated relevant information (Fig. 2). From this pop-up, it is possible to print out information regarding the selected element in PDF format. From the main page, it is also possible to access to the "list view" that shows, for the visualized elements, some common information throughout natural reefs, artificial reefs, and wrecks (Fig. 3). The number of visualized elements, in the top right corner of the map view, is updated accordingly to the output of data filtering operations.

From a technical point of view, data were entered in .csv format and then transformed in JSON objects as "collection of features" class, with prototype (generic) and object (specific) capabilities. For each element, an integer and consecutive identification number were assigned by default. The interactive map has been published using the GitHub Pages extension (https://pages.github.com/, last access: 3 May 2021), which represents an easy and rapid way to make information quickly available online. The base map coming from the open-source cooperative geographical project OpenStreetMap (https://www.openstreetmap.org/, last access: 3 May 2021) and the Nominatim package for geocoding operations (https://nominatim.openstreetmap.org/, last access: 3 May 2021) were used. The whole infrastructure is based on Searchable Map Template - CSV project (https:// github.com/datamade/searchable-map-template-csv, last access: 3 May 2021)

\section{Data analysis}

Data contained in the database can be analysed in many different ways and for different purposes. For example, Fig. 4, representing the wrecks' sink and the artificial reefs' deployment on time (excluding missing information elements), shows that until the end of the 1990s the majority of artificial structures occurring on the seabed of the Adriatic Sea were represented by wrecks, most of which had accidentally sunk. Afterwards, almost all the manmade structures deployed on the seabed were purposely constructed artificial reefs.

Another interesting example of analysis that can be performed on the data is the evaluation of the number of natural reefs subjected to any form of protection. Again, after deduction of "no data", it is possible to identify 31 Natura 2000 sites, 12 protected areas, 4 natural reserves, and 11 national parks (Fig. 5) with overlapping at some sites. Figure 5 also shows how NRs are distributed in these categories through Italian and Croatian waters. Coupling this graph with the information contained in Table 1, it results that almost the totality of the Italian natural reefs are subjected to some form of protection, while only half of the Croatian ones are under preservation constraints.

Also, the 3D representation of the sites can be useful for dissemination purposes. For example, in Fig. 6a all reefs and wrecks are reported over a bathymetric map of the Adriatic Sea. A section of the Tremiti Islands (Apulia, Italy), connecting three observations of the database, is reported in the zoom (panel b). 


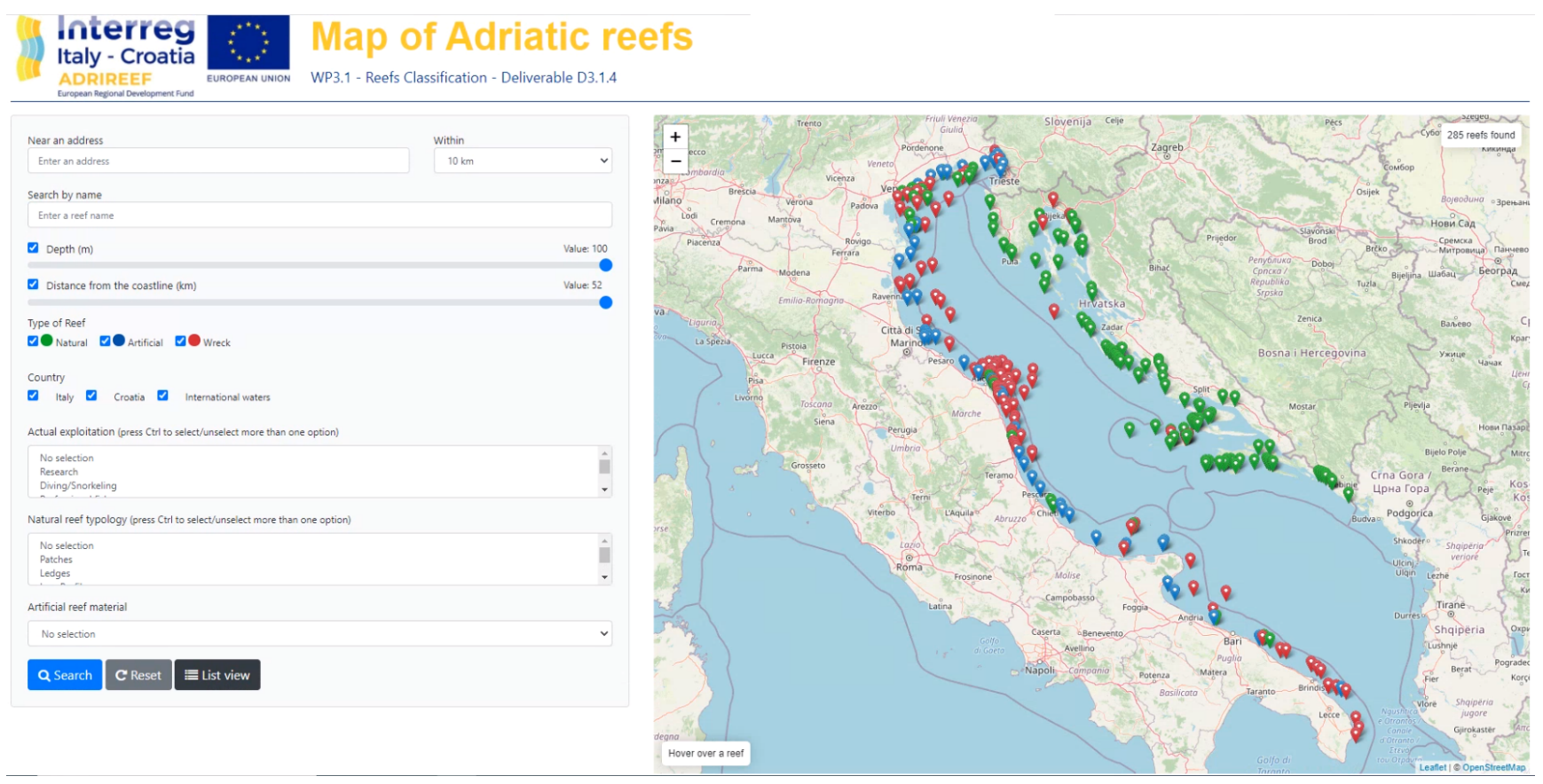

Figure 1. The WebGIS interface. On the left side: the filter window. On the right side: the map window with hover function (bottom left) and the total number of identified elements (top right). Basemap credits: () OpenStreetMap contributors 2020. Distributed under a Creative Commons BY-SA License.

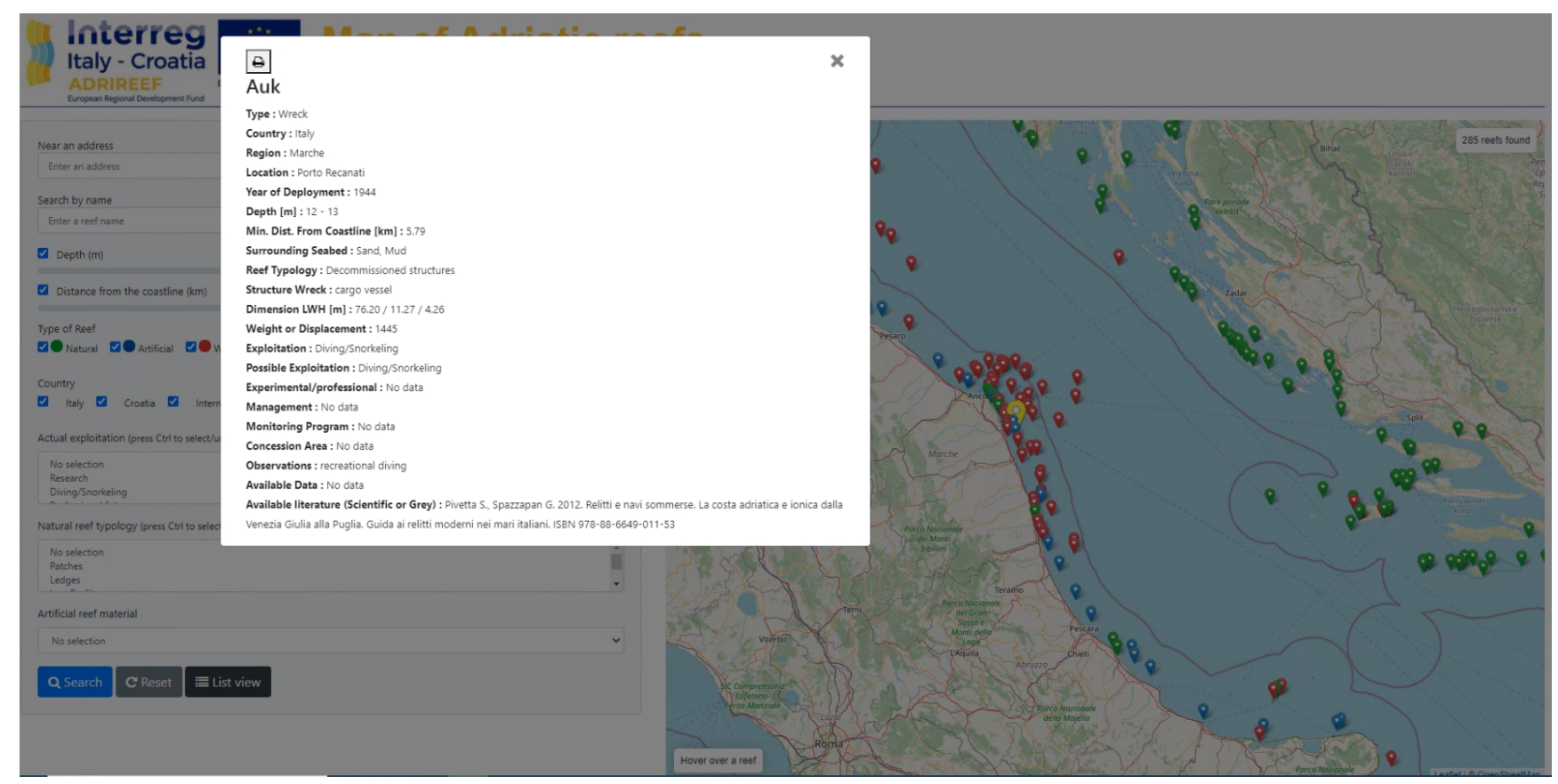

Figure 2. Example of the pop-up that appears once an element is clicked. Basemap credits: (C) OpenStreetMap contributors 2020. Distributed under a Creative Commons BY-SA License. 
Table 2. Column name, the current name of the parameter, type of parameter, unit of measure, origin of the information, and eventual applicability restrictions.

\begin{tabular}{|c|c|c|c|c|c|}
\hline Column name & Description & Group & Unit of measure & Origin of the data & Applicability \\
\hline type & type of reef/wreck & 1 & & DB manager & NRs, ARs, wrecks \\
\hline country & & 1 & & DB manager & NRs, ARs, wrecks \\
\hline region & & 1 & & DB manager & NRs, ARs, wrecks \\
\hline location & reference city or zone for the reef/wreck & 1 & & DB manager & NRs, ARs, wrecks \\
\hline name & common name of the reef/wreck & 1 & & Questionnaires & NRs, ARs, wrecks \\
\hline latitude & & 1 & [decimal degrees] & Questionnaires & NRs, ARs, wrecks \\
\hline longitude & & 1 & [decimal degrees] & Questionnaires & NRs, ARs, wrecks \\
\hline year_deployment & year of reef deployment/wreck sink & 1 & & Questionnaires & ARs, wrecks \\
\hline year_modification & year of eventual modification & 1 & & Questionnaires & ARs \\
\hline min_depth_m & bottom depth altitude & 2 & {$[\mathrm{~m}]$} & DB manager & NRs, ARs, wrecks \\
\hline depth_m & depth range covered by the structure & 2 & {$[\mathrm{~m}]$} & Questionnaires & NRs, ARs, wrecks \\
\hline reef_edge_m & height of the structure & 2 & {$[\mathrm{~m}]$} & Questionnaires & NRs \\
\hline min_dist_km & minimum distance from the coastline & 2 & {$[\mathrm{~km}]$} & Questionnaires & NRs, ARs, wrecks \\
\hline surrounding_seabed & surrounding seabed sedimentary composition & 2 & & Questionnaires & NRs, ARs, wrecks \\
\hline meadows & presence of meadows & 2 & & Questionnaires & NRs, ARs, wrecks \\
\hline reef_typology & reef typology & 3 & & Questionnaires & NRs \\
\hline structure_wreck & type of wreck & 3 & & Questionnaires & Wrecks \\
\hline material & material composing the reef & 3 & & Questionnaires & ARs \\
\hline arrangement_modules & global arrangement of modules composing the reef & 3 & & Questionnaires & ARs \\
\hline origin_reef & origin of the reef & 3 & & Questionnaires & NRs \\
\hline total_area_sqm & total footprint area of the reef & 3 & {$\left[\mathrm{~m}^{2}\right]$} & Questionnaires & NRs, ARs \\
\hline total_volume_cubm & total volume of the reef & 3 & {$\left[\mathrm{~m}^{3}\right]$} & Questionnaires & ARs \\
\hline n_oases & number of oases, composed by structures & 3 & & Questionnaires & ARs \\
\hline dist_between_oases_m & linear distance between oases & 3 & {$[\mathrm{~m}]$} & Questionnaires & ARs \\
\hline dimens_oases_sqm & footprint area of the oases & 3 & {$\left[\mathrm{~m}^{2}\right]$} & Questionnaires & ARs \\
\hline type_structures & $\begin{array}{l}\text { type of structures present in the reef, composed of mod- } \\
\text { ules }\end{array}$ & 3 & & Questionnaires & ARs \\
\hline n_structures & number of structures present in the reef & 3 & & Questionnaires & ARs \\
\hline dim_structures_m & relevant dimensions of the structures of the reef & 3 & {$[\mathrm{~m}]$} & Questionnaires & ARs \\
\hline dist_between_structures_m & linear distance between structures of the reef & 3 & {$[\mathrm{~m}]$} & Questionnaires & ARs \\
\hline modules_shape & shape of the modules composing the structures of the reef & 3 & & Questionnaires & ARs \\
\hline n_modules & number of modules composing the structures of the reef & 3 & & Questionnaires & ARs \\
\hline dist_between_modules_m & $\begin{array}{l}\text { linear distance between modules composing the structures } \\
\text { of the reef }\end{array}$ & 3 & {$[\mathrm{~m}]$} & Questionnaires & ARs \\
\hline dimension_leng_width_heigh_m & dimensions length, height, width of the reef/wreck & 3 & {$[\mathrm{~m}, \mathrm{~m}, \mathrm{~m}]$} & Questionnaires & ARs, wrecks \\
\hline weight_or_displacement_tons & weight or displacement of the wreck & 3 & [tonnes] & Questionnaires & Wrecks \\
\hline experimental_professional & $\begin{array}{l}\text { describes the type of exploitation, if professional or exper- } \\
\text { imental, of the reef }\end{array}$ & 4 & & Questionnaires & ARs \\
\hline scope & describes original conception scopes of the reef & 4 & & Questionnaires & ARs \\
\hline exploitation & current exploitation of the reef/wreck & 4 & & Questionnaires & NRs, ARs, wrecks \\
\hline possible_exploitation & potential exploitation of the reef/wreck & 4 & & Questionnaires & NRs, ARs, wrecks \\
\hline observations & additional observations & 3 & & Questionnaires & Wrecks \\
\hline biocoenosis & presence (and types, if available) of biocoenosis & 2 & & Questionnaires & NRs \\
\hline alien_species & presence (and names, if available) of alien species & 2 & & Questionnaires & NRs \\
\hline protected_species & presence (and names, if available) of protected species & 2 & & Questionnaires & NRs \\
\hline protected_area & presence of a protected area where the reef is placed & 2 & & Questionnaires & NRs \\
\hline management_prog_Y_N & $\begin{array}{l}\text { existing of a management programme insisting on the } \\
\text { reef/wreck }\end{array}$ & 2 & & Questionnaires & NRs, ARs, wrecks \\
\hline management_body & $\begin{array}{l}\text { name of the management body of the reef/wreck (if appli- } \\
\text { cable) }\end{array}$ & 2 & & DB manager & NRs, ARs, wrecks \\
\hline concession_area_Y_N & presence of a concession area insisting on the reef/wreck & 2 & & Questionnaires & ARs, wrecks \\
\hline surveillance_service & $\begin{array}{l}\text { presence (and name, if available) of a surveillance service } \\
\text { on reef/wreck }\end{array}$ & 2 & & Questionnaires & NRs, ARs, wrecks \\
\hline current_monitoring_program_Y_N & $\begin{array}{l}\text { presence of a current monitoring programme on } \\
\text { reef/wreck }\end{array}$ & 2 & & Questionnaires & NRs, ARs, wrecks \\
\hline monitoring_programs & $\begin{array}{l}\text { present or past monitoring programme insisting on the } \\
\text { reef/wreck }\end{array}$ & 2 & & Questionnaires & NRs, ARs, wrecks \\
\hline available_data & eventually available data related to the reef/wreck & - & & Questionnaires & NRs, ARs, wrecks \\
\hline available_literature & available literature, scientific or grey & - & & Questionnaires & NRs, ARs, wrecks \\
\hline
\end{tabular}

\section{Data availability}

The database is currently available for download through the SEANOE (https://www.seanoe.org/, last access: 3 May 2021) repository, and it is reachable at the following
URL: https://doi.org/10.17882/74880 (Ferrà et al., 2020). The dataset is also published in the EMODnet (European Marine Observation Data network; Novellino et al., 2015) Data Ingestion Portal, and it is currently undergoing the required procedure to be published into the EMODnet 


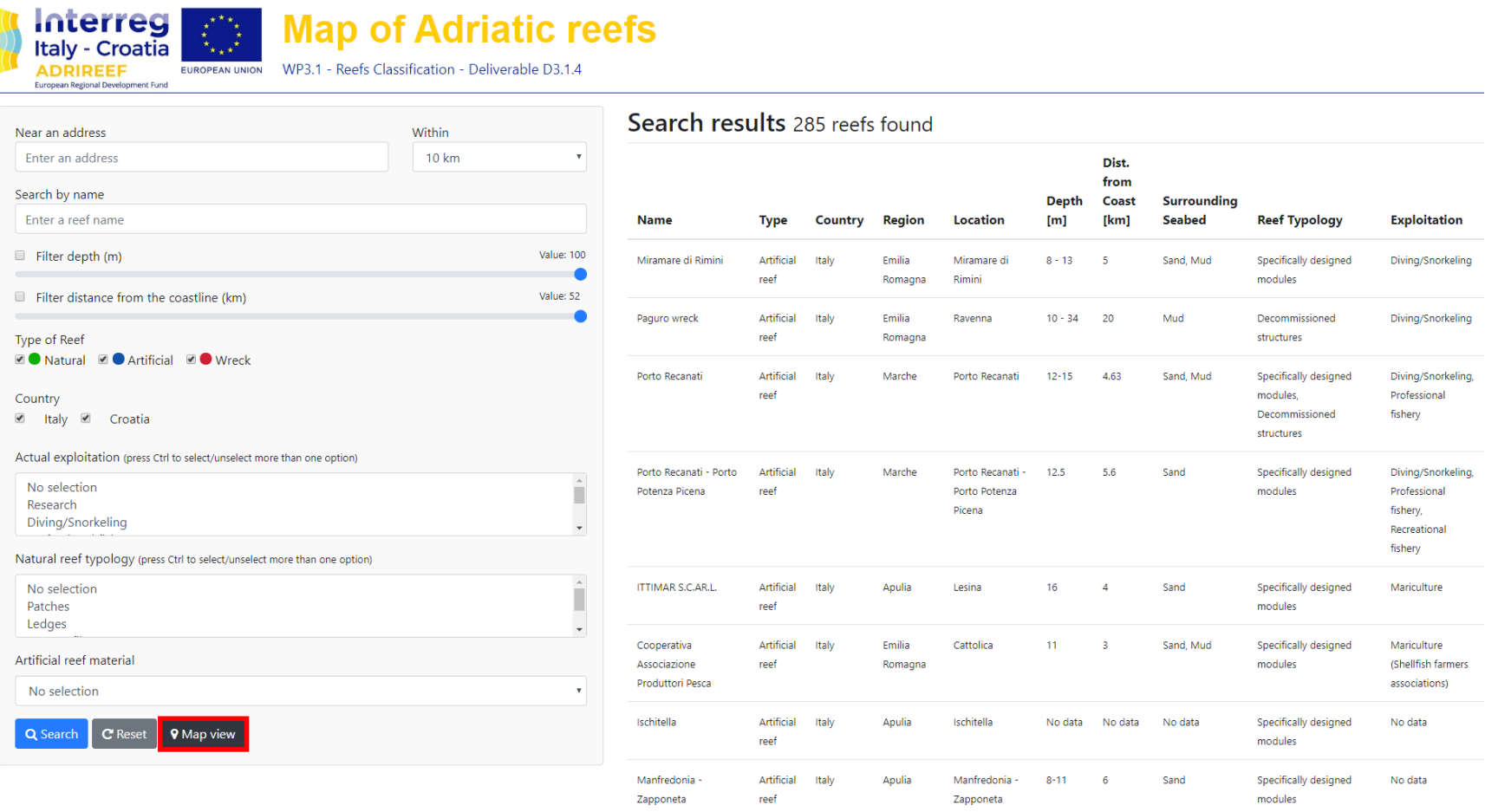

Figure 3. List view. Once elements are selected, it is possible to obtain some common information by clicking the "List view" button (that turns into "Map view" when the list is visualized, evidenced in red).

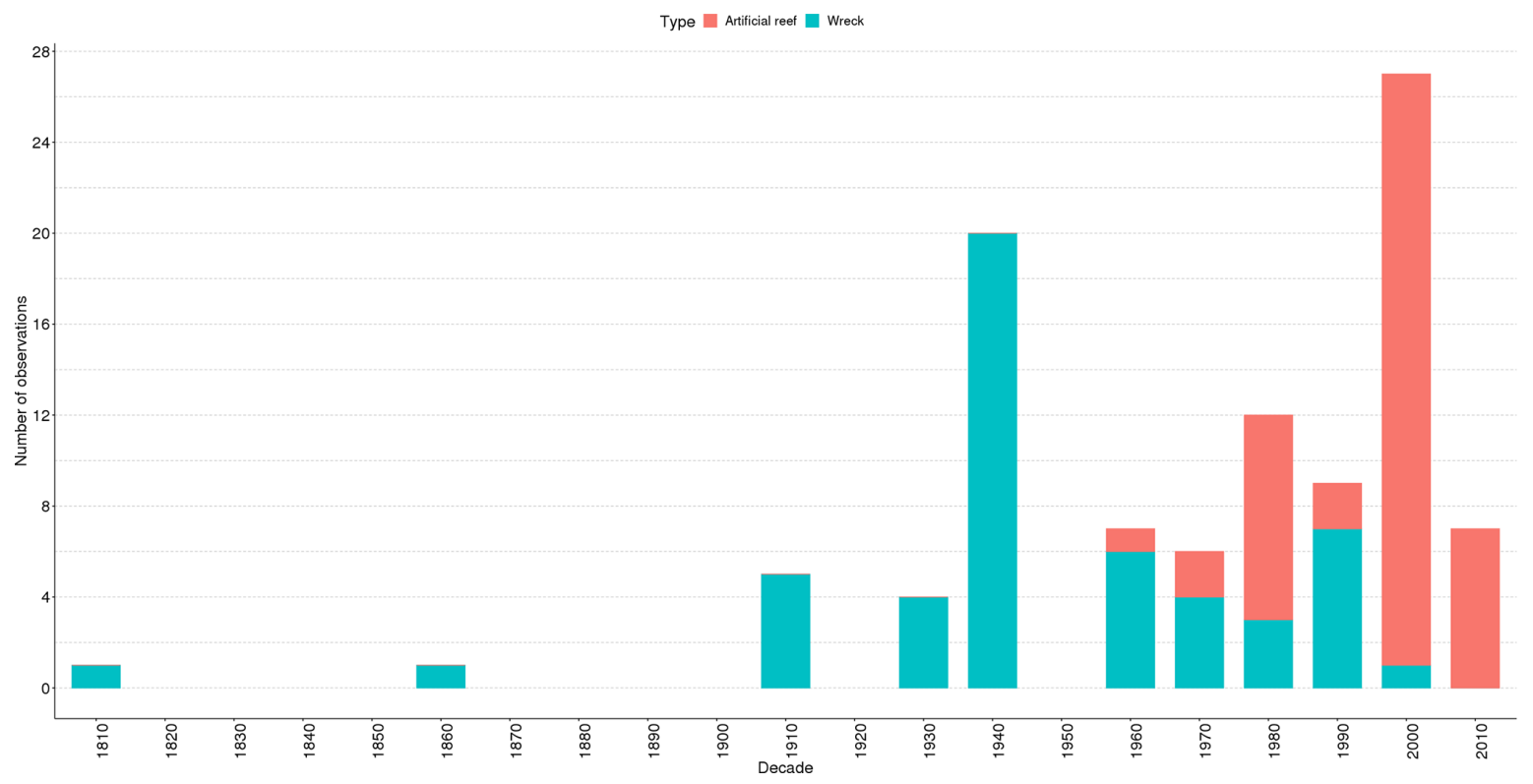

Figure 4. Artificial reefs and wrecks by year of deployment at the decadal scale.

catalogues. EMODnet was chosen for two main reasons: it ensures long-term data availability and has increasingly become a reference point for all available European maritime data (Martín Míguez et al., 2019). In fact, the platform was financed in the framework of the EU's Integrated Maritime Policy definition (Commission of the European
Communities, 2007) to unlock existing but fragmented and hidden marine data and make them freely accessible for a wide range of users (Calewaert et al., 2016), while respecting FAIR data management principles (Findable, Accessible, Interoperable, Reusable; Wilkinson et al., 2016). In this way, an invaluable heritage of marine data were 


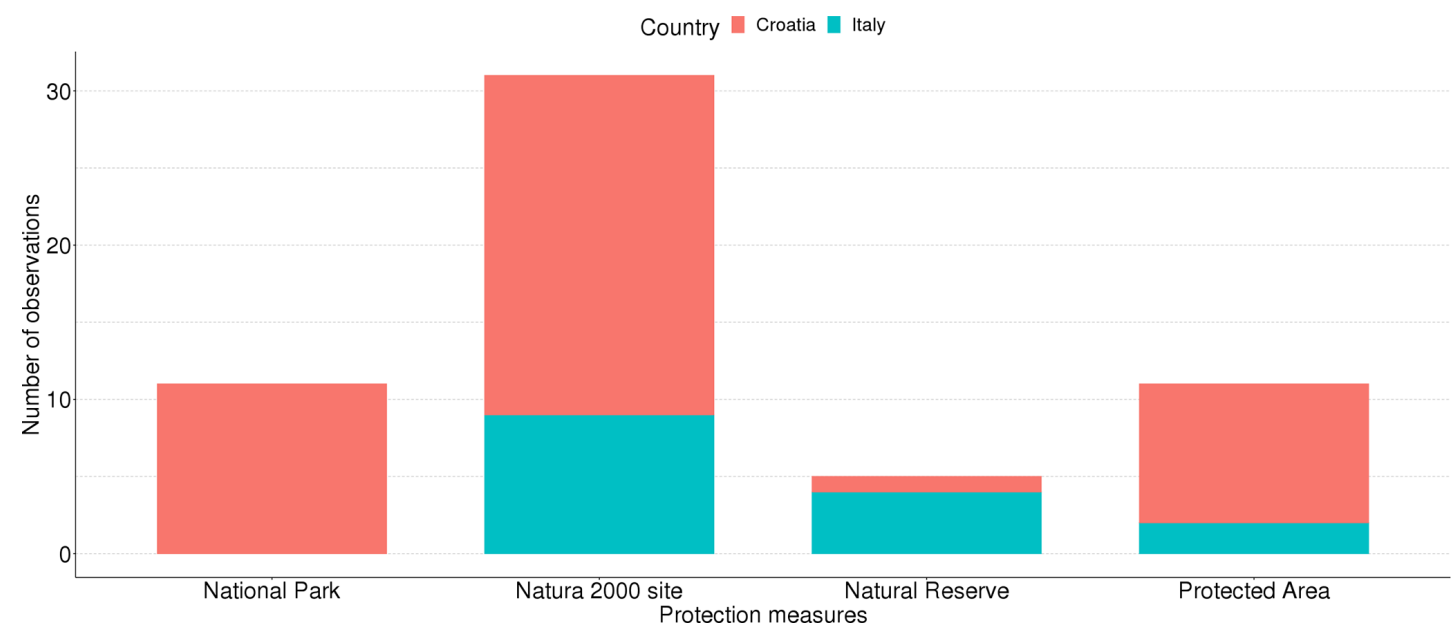

Figure 5. Protection measures applied to natural reefs in Croatia and in Italy.
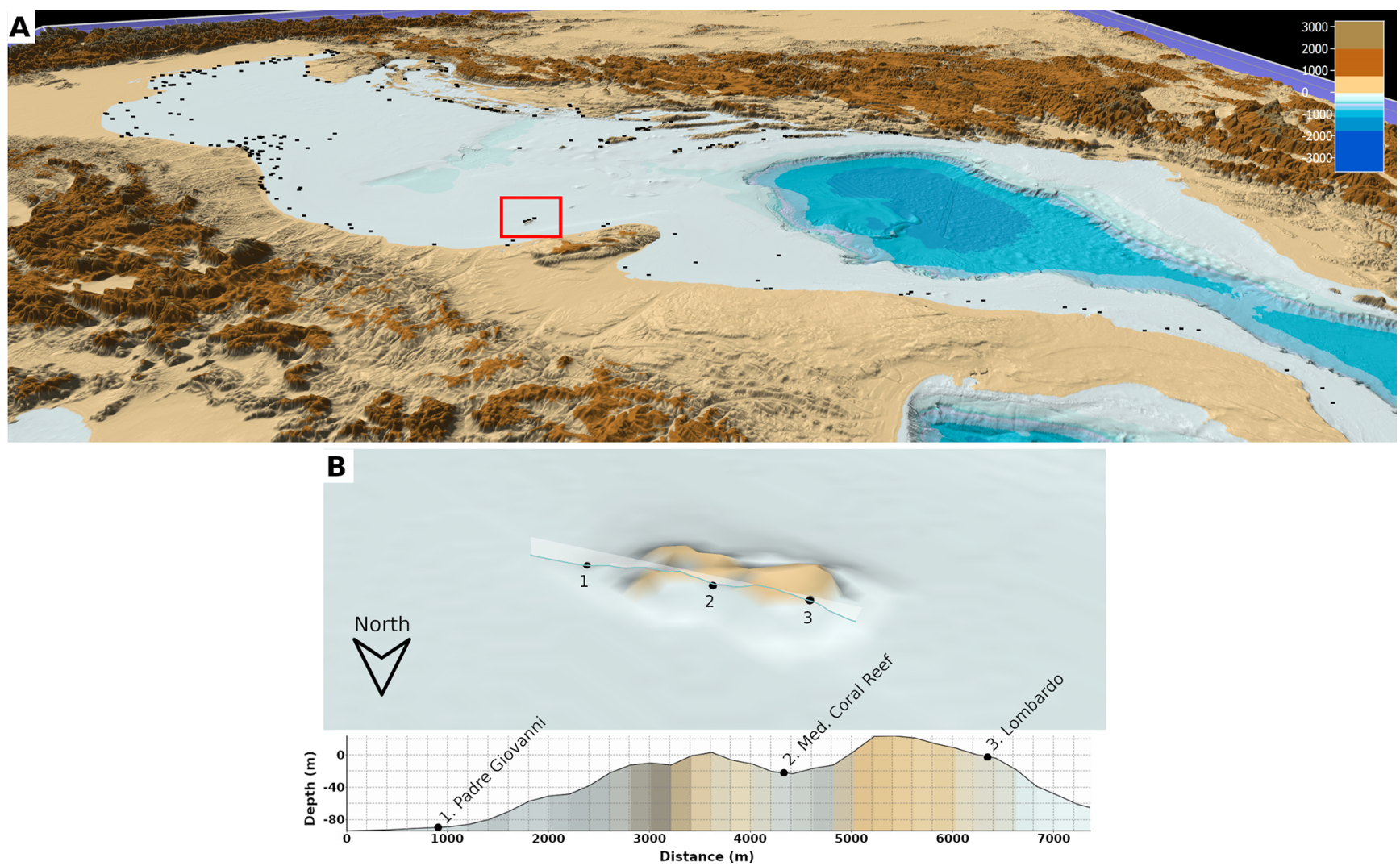

Figure 6. A 3D visualization of the spatial distribution of natural reefs, artificial reefs, and wrecks in the Adriatic Sea (a). In the red square, the area concerning the zoom reported below. A view of Tremiti Islands and the vertical terrain section from left to right crossing three elements (b): Padre Giovanni and Lombardo wrecks (points no. 1 and 3) and Mediterranean mesophotic coral reef (point no. 2).

collected, and all data uploaded in EMODnet are indexed in Web Of Science. The database was released under the Creative Commons Attribution license (CC-BY, v. 4.0, https://creativecommons.org/licenses/by/4.0/deed.it, last access: 3 May 2021).

\section{Conclusions}

The data collection work and publication represent an unprecedented, consistent, and robust recognition of the reefs and wrecks in the Adriatic Sea. The database represents a comprehensive collection providing a well-detailed state 
of the art and some hints on possible future exploitation of reefs and wrecks in this geographical zone and a tool to implement the EUSAIR strategy (European Commission, 2014), aimed at promoting economic and social prosperity and growth in the Adriatic-Ionian region by creating synergies and fostering coordination in some thematic pillars: sustainable tourism, environmental quality, connecting the region, and, in wider terms, the Blue Growth (European Commission, 2017).

Indeed, the collected information can be useful for different purposes, from spatial management, to the strengthening of some economic activities and/or development of new ones taking into account the local environmental features

Knowing the environmental status and current exploitation level of reefs/wrecks located in a specific geographical area is in fact fundamental to identify potential additional ecosystem services they can provide and, consequently, develop sustainable economic activities with subsequent positive impacts on the local communities (Costanza et al., 2014). In addition, from the research point of view, a comprehensive database like the one presented here could be a starting point for the implementation of ecological studies where the information is still scarce or lacking as well as of monitoring programmes aimed at evaluating the impact of some economic activities (e.g. tourism, small-scale fisheries) on sensitive habitats.

Lastly, the interactive map represents a tool that allows, through the simultaneous usage of different filters, to highlight and quantify particularly interesting situations in a userfriendly and quick manner, so as to be also easily handled by the wider public. It could be, for example, used by tourists to identify suitable and less known sites for recreational activities such as snorkelling, diving, and sailing.

Overall, the provided collection can be helpful to increase visibility and attractiveness of reefs and wrecks existing in the Adriatic Sea while increasing awareness of both policy makers and citizens towards the need of managing and exploiting these sites in a sustainable way in order to assure their preservation over time.

The general perception derived from an overall evaluation of the collected data is that, in the Adriatic context, reefs and wrecks still represent an underestimated environmental heritage that, if adequately preserved and promoted, could provide new opportunities for developing activities in line with the Blue Economy in the near future. 


\section{Appendix A: Natural reef questionnaire}

1. Name and surname:

2. Occupational qualification and workplace:

3. Name of the reef:

4 Location of the reef:

5. Geographical coordinates latitude (WGS84 DD.DD., e.g. 43.023N):

6. Geographical coordinates longitude (WGS84 DD.DD., e.g. 13.123N):

7. Reef bottom depth (m) (if it is in a range, please specify the max and min):

8. $\quad$ Reef edge $(\mathrm{m})$ :

9. Minimum distance from the coast $(\mathrm{km})$ :

10. Total area occupied by the natural reef $\left(\mathrm{m}^{2}\right)$ :

11. Typology of the reef:

$\square$ High-profile reef (the reef protrudes more than $20 \mathrm{~m}$ from the base substratum)

$\square$ Low-profile reef (the reef protrudes less than $20 \mathrm{~m}$ from the base substratum)

$\square$ Ledges (vertical reef face characterized by visible crevices)

$\square$ Boulder reef (structure elevating from the flat seabed)

$\square$ Patch reef (sand bottom with small reef structures protruding from the sediment)

$\square$ I do not know

12. Origin of the reef:

$\square$ Biogenic

$\square$ Geogenic

13. Type of surrounding seabed:
$\square$ Rocks
$\square$ Sand
$\square$ Mud
$\square$ Detritic
$\square$ Gravel
$\square$ Other

14. Occurrence of meadows?
$\square$ Yes, phanerogams
$\square$ Yes, algae
$\square$ No

15. What are the most important biocenoses?

16. Any alien species?
$\square$ Yes
$\square$ No
$\square$ Maybe

17. If "Yes", which alien species?

18. Any protected species? (e.g. IUCN Red List of Threatened Species, ASPIM Protocol, Berna Convention)
$\square$ Yes
$\square$ No
$\square$ Maybe
$\square$ If "Yes", which species?

19. Is the natural reef within a protected area?
$\square$ Yes, MPA
$\square$ Yes, Natura 2000 site
$\square$ Yes, national park
$\square$ Yes, natural park
$\square$ Yes, marine reserve
$\square$ No 
20. Is the reef managed?
$\square$ Yes
$\square$ No
$\square$ I do not know

21. If yes, what is the managing subject? (please give a short summary of the management measures adopted)

22. Does a monitoring program exist?

$\square$ Yes

$\square$ No

$\square$ If "Yes" please give a short summary of the program

24. Surveillance service?

$\square$ Yes

$\square$ No

25. Current use of the reef:

$\square$ Diving

$\square$ Mariculture

$\square$ Research

$\square$ Professional fishery

$\square$ Recreation fishery

$\square$ Fishing tourism

$\square$ Nothing

$\square$ Other (please, specify)

26. Development perspectives of the natural reef:
$\square$ Diving
$\square$ Mariculture
$\square$ Research
$\square$ Professional fishery
$\square$ Recreation fishery
$\square$ Fishing tourism
$\square$ Nothing
$\square$ Other (please, specify)

27. Please list the available data (if "Other" please specify):

$\square$ Geophysical map

$\square$ Water column

$\square$ Sediments

$\square$ Benthic community

$\square$ Fish community

$\square$ Other (please, specify)

28. Available literature (scientific or grey):

(please add as many papers/works you know about the reef using the following scheme:

title / authors / year of publication / journal or project / pages / abstract / keywords) 


\section{Appendix B: Artificial reef questionnaire}

1. Name and surname:

2. Occupational qualification and workplace:

3. Name of the reef:

4. Location of the reef:

5. Geographical coordinates latitude (WGS84 DD.DD., e.g. 43.023N):

6. Geographical coordinates longitude (WGS84 DD.DD., e.g. 13.123N):

7. Year of deployment of the AR:

8. Year of modification of the AR:

9. Bottom depth ( $\mathrm{m}$ ) (if it is in a range, please specify the max and min):

10. Minimum distance from the coast $(\mathrm{km})$ :

11. Type of surrounding seabed:
$\square$ Rocks
$\square$ Sand
$\square$ Mud
$\square$ Detritic
$\square$ Gravel
$\square$ Other (please, specify)

12. Occurrence of meadows?
$\square$ Yes, phanerogams
$\square$ Yes, algae
$\square$ No

Artificial reef structure

1. Reef typology:

$\square$ Specifically designed modules (basic module)

$\square$ Decommissioned structures

$\square$ Other (please, specify)

\section{Specifically designed modules (basic module)}

1. Material:

$\square$ Concrete

$\square$ Sea-friendly concrete (e.g. Tecnoreef)

$\square$ Coal ash

$\square$ Rocks

$\square$ Fibreglass

$\square$ Other (please specify)

2. Shape of the single module:

$\square$ Cube

$\square$ Pole

$\square$ Plinth

$\square$ Other (please, specify)

3. Dimension of the single module $(\mathrm{m})$ :

4. Total volume of deployed material $\left(\mathrm{m}^{3}\right)$ :

5. Arrangement of the modules:

$\square$ Geometrically assembled to form structures

$\square$ Scattered

$\square$ Other (please, specify)

Artificial reef geometrically assembled to form structures

$\square$ Typology (e.g. pyramid)

$\square$ Number of deployed structures:

$\square$ Height of the structures (m):

$\square$ Distance among structures (m): 
$\underline{\text { Scattered artificial reef }}$

1. Number of deployed structures:

2. Distance between structures $(\mathrm{m})$ :

If the artificial reef is composed by areas or oases, please indicate the following:

1. Number of the oases:

2. Distance among oases:

3. Dimension of each oasis $\left(\mathrm{m}^{2}\right)$ :

4. Total area occupied by the artificial reef (including the area covered by the bodies, the distance between the bodies and the area of respect) $\left(\mathrm{m}^{2}\right)$ :

\section{Decommissioned structures}

Please specify the nature of the structure:

$\square$ Offshore extraction platform

$\square$ Purposely sunk vessel/ship

$\square$ Other (please, specify)

Offshore extraction platform:

1. Type of the platform (e.g. one-leg platform):

2. Part of the platform used to realize the AR (e.g. jacket, deck):

3. Total area occupied by the artificial reef $\left(\mathrm{m}^{2}\right)$ :

Purposely sunk vessel/ship:

1. Number of sunk vessels:

2. Vessel material:

$\square$ Wood

$\square$ Iron

$\square$ Fibreglass

$\square$ Other (please, specify)

3. Dimension of the sunk vessel/ship - LWH (m) and weight (tonne):

Other artificial reefs:

1. Number of bodies:

2. Material of bodies:

$\square$ Wood

$\square$ Iron

$\square$ Fibreglass

$\square$ Concrete

$\square$ Other (please, specify)

3. Dimension of each body - length (m) and weight (tonne):

\section{Artificial reef utilization}

1. Scope:

$\square$ Habitat protection

$\square$ Habitat restoration

$\square$ Finfish enhancement

$\square$ Diving

$\square$ Mariculture

$\square$ Research

$\square$ Professional fishery

$\square$ Recreational fishery

$\square$ Fishing tourism

$\square$ Other (please, specify)

2. Type of artificial reef:

$\square$ Experimental

$\square$ Professional 
3. Is the reef exploited at present?

$\square$ Yes

$\square$ No

$\square$ Maybe

If "Yes", by whom?

4. Does a management program exist?

$\square$ Yes

$\square$ No

$\square$ Maybe

If "Yes", please specify the managing subject and give a short summary of the adopted management measures

5. Concession area?

$\square$ Yes

$\square$ No

6. Surveillance service?

$\square$ Yes

$\square$ No

7. Does a monitoring program exist?

$\square$ Yes

$\square$ No

$\square$ Maybe

If "Yes", please give a short summary (duration / monitored aspects / involved institute or agency / address, e-mail address)

8. Possible exploitation of the artificial reef:
$\square$ Diving
$\square$ Mariculture
$\square$ Research
$\square$ Professional fishery
$\square$ Recreational fishery
$\square$ Fishing tourism
$\square$ Nothing
$\square$ Other (please, specify)

9. Please list the available data:

$\square$ Geophysical map

$\square$ Water column

$\square$ Sediments

$\square$ Benthic community

$\square$ Fish community

$\square$ Other (please, specify)

10. Available literature (scientific or grey):

(please add as many papers/works you know about the reef using the following scheme:

title/ authors / year of publication / journal or project / pages / abstract / keywords) 


\section{Appendix C: Wreck questionnaire}

1. Name and surname:

2. Occupational qualification and workplace:

3. Name of the wreck:

4. Location of the wreck:

5. Geographical coordinates latitude (WGS84 DD.DD., e.g. 43.023N):

6. Geographical coordinates longitude (WGS84 DD.DD., e.g. 13.123N):

7. Year of accidental sinking of the wreck:

8. Bottom depth ( $\mathrm{m}$ ) (if it is in a range, please specify the max and min):

9. Minimum distance from the coast $(\mathrm{km})$ :

10. Type of surrounding seabed:
$\square$ Rocks
$\square$ Sand
$\square$ Mud
$\square$ Detritic
$\square$ Gravel
$\square$ Other (please, specify)

11. Occurrence of meadows?
$\square$ Yes, phanerogams
$\square$ Yes, algae
$\square$ No

12. Vessel material:
$\square$ Wood
$\square$ Iron

$\square$ Fibreglass

$\square$ Other (please, specify)

13. Total area occupied by the wreck $\left(\mathrm{m}^{2}\right)$ :

14. Total volume of the wreck $\left(\mathrm{m}^{3}\right)$ :

15. Eventual fragments of the wreck and their spatial configuration:

16. Dimension of the sunk vessel/ship - LWH (m) and weight (tonne):

17. Is the wreck exploited at present?
$\square$ Yes
$\square$ No
$\square$ Maybe
$\square$ If "Yes", by whom?

18. Does a management program exist?
$\square$ Yes
$\square$ No

$\square$ Maybe

$\square$ If "Yes", please specify the managing subject and give a short summary of the adopted management measures

19. Concession area?
$\square$ Yes
$\square$ No

20. Surveillance service?
$\square$ Yes
$\square$ No 
21 Does a monitoring program exist?

$\square$ Yes

$\square$ No

$\square$ Maybe

$\square$ If "Yes", please give a short summary (duration / monitored aspects / involved institute or agency / address, email address)

22. Possible exploitation of the wreck:
$\square$ Diving
$\square$ Mariculture
$\square$ Research
$\square$ Professional fishery
$\square$ Recreational fishery
$\square$ Fishing tourism
$\square$ Nothing
$\square$ Other (please, specify)

23. Please list the available data:

$\square$ Geophysical map

$\square$ Water column

$\square$ Sediments

$\square$ Benthic community

$\square$ Fish community

$\square$ Other (please, specify)

24. Available literature (scientific or grey):

(please add as many papers/works you know about the reef using the following scheme:

title/ authors / year of publication / journal or project / pages / abstract / keywords) 
Supplement. The supplement related to this article is available online at: https://doi.org/10.5194/essd-13-1905-2021-supplement.

Author contributions. AM, CF, GF, and ANT conceptualized the paper. $\mathrm{AM}$ and $\mathrm{CF}$ analysed the data and wrote the original draft. AM, ANT, GF, AS, MSc, MSo, and DB reviewed and edited the manuscript. CF, AS, MSc, ANT, GF, CRF, CM, SP, ZJ, TŠ, MŠ, CK, DP, EB, MDG, DB, EG, RA, IB, ĐVS, SO, VF, DZ, IOK, MSo, and $\mathrm{SU}$ contributed to the collection and curation of data described in this paper. AM worked at data visualization. GF supervised the whole work.

Competing interests. The authors declare that they have no conflict of interest.

Financial support. The present work was funded by the European Regional Development Fund in the frame of the project ADRIREEF (Innovative exploitation of Adriatic Reefs in order to strengthen blue economy), project ID: 10045901. Interreg VA Italy Croatia Cross-border Cooperation Programme 2014-2020.

Review statement. This paper was edited by Jens Klump and reviewed by Chiara Venier and Sarretta Alessandro.

\section{References}

Alempijević, A. and Kovačić, M.: Nautical Tourism and Small Shipbuilding as Significant part of Blue Economy Development, Pomorski Zbornik, 57, 97-110, https://doi.org/10.18048/2019.57.07, 2019.

Calewaert, J. B., Weaver, P., Gunn, V., Gorringe, P., and Novellino, A.: The European Marine Data and Observation Network (EMODnet): Your Gateway to European Marine and Coastal Data, in: Quantitative Monitoring of the Underwater Environment, Ocean Engineering \& Oceanography, edited by: Zerr, B., Jaulin, L., Creuze, V., Debese, N., Quidu, I., Clement, B., and Billon-Coat, A., Springer, Cham, Vol. 6, https://doi.org/10.1007/978-3-319-32107-3_4, 2016.

Cater, C. and Cater, E.: Marine ecotourism: Between the devil and the deep blue sea, Vol. 6, Cab Intl., ISBN: 9781845932596, 2007.

Commission of the European Communities: Commission staff working document, Accompanying document to the communication from the commission to the European parliament, the council, the European economic and social committee and the committee of the regions: An Integrated Maritime Policy for the European Union, SEC(2007) 1278, 2007.

Costanza, R., De Groot, R., Sutton, P., Van der Ploeg, S., Anderson, S. J., Kubiszewski, I., Farber, S., and Turner, R. K.: Changes in the global value of ecosystem services, Global Environ. Change, 26, 152-158, https://doi.org/10.1016/j.gloenvcha.2014.04.002, 2014.

EU Directive 2014/89/EU: the European Parliament and of the Council of 23 July 2014 establishing a framework for maritime spatial planning, Official Journal of the European Union
L 257/135 L257, p. 135, available at: https://eur-lex.europa.eu/ legal-content/EN/TXT/?uri=CELEX\%3A32014L0089 (last access: 5 February 2021), 2014.

Douvere, F.: The importance of marine spatial planning in advancing ecosystem-based sea use management, Mar. Policy, 32, 762771, https://doi.org/10.1016/j.marpol.2008.03.021, 2008.

Edney, J.: Understanding wreck divers: Case studies from Australia and Chuuk Lagoon, in: Proceedings of the Asia-Pacific Regional Conference on Underwater Cultural Heritage, 575-587, 8-12 November 2011.

European Commission: Directive 2008/56/EC of the European Parliament and of the Council of 17 June 2008 establishing a framework for community action in the field of marine environmental policy (Marine Strategy Framework Directive), 164, 2008.

European Commission: European Commission, Commission Staff Working Document: Action Plan Accompanying the document Communication from the commission to the european parliament, the council, the european economic and social committee and the committee of the regions concerning the European Union Strategy for the Adriatic and Ionian Region, SWD(2014) 190 final, available at: https://www.adriatic-ionian.eu/wp-content/ uploads/2018/04/EUSAIR-ACTION-PLAN-17-June-2014.pdf (last access: 9 March 2021), 17 June 2014.

European Commission: European Commission, Commission staff working document, Report on the Blue Growth Strategy Towards more sustainable growth and jobs in the blue economy, $\operatorname{SWD}(2017) 128$ final, available at: https://ec.europa.eu/maritimeaffairs/sites/maritimeaffairs/ files/swd-2017-128_en.pdf, (last access: 9 March 2021), 31 March 2017.

Fabi, G., Spagnolo, A., Bellan-Santini, D., Charbonnel, E., Çiçek, B. A., García, J. J. G., Jensen, A. C., Kallianiotis, A., and Santos, M. N. D.: Overview on artificial reefs in Europe, Braz. J. Oceanogr., 59, 155-166, https://doi.org/10.1590/S1679$87592011000500017,2011$.

Fabi, G., Sarcella, G., Spagnolo, A., Bortone, S. A., Charbonnel, E., Goutayer, J. J., Naoufel, H., Lök, A., and Trommelen, M.: Practical guidelines for the use of artificial reefs in the Mediterranean and the Black Sea, General Fisheries Commission for the Mediterranean, Studies and Reviews, 96, 87 pp., ISBN: 978-925-108854-8, 2015.

Ferrà, C., Minelli, A., Spagnolo, A., Scanu, M., Tassetti, A. N., Ferrari, C. R., Mazziotti, C., Pigozzi, S., Jakl, Z., Šarčević, T., Šimac, M., Kruschel, C., Pejdo, D., Barbone, E., De Gioia, M., Borme, D., Gordini, E., Auriemma, R., Benzon, I., VukovićStanišić, Đ., Orlić, S., Frančić, V., Zec, D., Orlić Kapović, I., Soldati, M., Uliazzi, S. and Fabi, G.: The ADRIREEF database: natural/artificial reefs and wrecks in the Adriatic Sea, SEANOE, https://doi.org/10.17882/74880, 2020.

Gilliland, P. M. and Laffoley, D.: Key elements and steps in the process of developing ecosystem-based marine spatial planning, Mar. Policy, 32, 787-796, https://doi.org/10.1016/j.marpol.2008.03.022, 2008.

Ilieva, I., Jouvet, L., Seidelin, L., Best, B. D., Aldabet, S., da Silva, R., and Conde, D. A.: A global database of intentionally deployed wrecks to serve as artificial reefs, Data in Brief, 23, 103584, https://doi.org/110.1016/j.dib.2018.12.023, 2019.

Kiper, T.: Role of ecotourism in sustainable development, in: Advances in Landscape Architecture, edited by: Özyavuz, M., In- 
Tech, 773-802, https://doi.org/10.5772/51738, ISBN: 978-95351-1167-2, 2013.

Martín Míguez, B., Novellino, A., Vinci, M., Claus, S., Calewaert, J. B., Vallius, H., Schmitt, T., Pititto, A., Giorgetti, A., Askew, N., Iona, S., Schaap, D., Pinardi, N., Harpham, Q., Kater, B. J., Populus, J., She, J., Palazov, A. V., McMeel, O., Oset, P., Lear, D., Manzella, G. M. R., Gorringe, P., Simoncelli, S., Larkin, K., Holdsworth, N., Arvanitidis, C. D., Molina Jack, M. E., Chaves Montero, M. M., Herman, P. M. J., and Hernandez, F.: The European Marine Observation and Data Network (EMODnet): Visions and Roles of the Gateway to Marine Data in Europe, Front. Mar. Sci., 6, 313, https://doi.org/10.3389/fmars.2019.00313, 2019.

Needham, M. D.: Value orientations toward coral reefs in recreation and tourism settings: a conceptual and measurement approach, J. Sustain. Tour., 18, 757-772, https://doi.org/10.1080/09669581003690486, 2010.

Novellino, A., D’Angelo, P., Benedetti, G., Manzella, G., Gorringe, P., Schaap, D., Pouliquen, S., and Rickards, L.: European marine observation data network - EMODnet physics, in: OCEANS 2015 - Genova, 1-6, https://doi.org/10.1109/OCEANSGenova.2015.7271548, 2015.

Nurhayati, A., Aisah, I., and Supriatna, A. K.: Model Development of A Synergistic Sustainable Marine Ecotourism - A Case Study in Pangandaran Region, West Java Province, Indonesia, Sustainability, 11, 3418, https://doi.org/10.3390/su11123418, 2019.

Oliver, J., Noordeloos, M., Yusuf, Y., Tan, M., Nayan, N., Foo, C., and Shahriyah, F.: ReefBase: a global information system on coral reefs, WorldFish Center, ReefBase Project, 2002.

Orams, M. B.: Marine ecotourism as a potential agent for sustainable development in Kaikoura, New Zealand, Int. J. Sust. Dev., 5, 338-352, https://doi.org/10.1504/IJSD.2002.003757, 2002.

Pauly, D.: A vision for marine fisheries in a global blue economy, Mar. Policy, 87, 371-374, https://doi.org/10.1016/j.marpol.2017.11.010, 2018.

Pivetta, S. and Spazzapan, G.: Relitti e navi sommerse, La costa adriatica e ionica dalla Venezia Giulia alla Puglia, Guida ai relitti moderni nei mari italiani, Addictions-Manages Editoriale, ISBN: 9788866490111, 2012.

Sakellariadou, F. and Kostopoulou, E.: Marine ecotourism from the perspective of the blue growth, Conference 7th iCOnEc Conference Competitiveness and Stability in the Knowledge-based Economy, Craiova, Romania, available at: https://www.researchgate.net/publication/317142241_Marine_ ecotourism_from_the_perspective_of_blue_growth (last access: 17 February 2020), 2015.

Spalding, M., Burke, L., Wood, S. A., Ashpole, J., Hutchison, J., and $\mathrm{Zu}$ Ermgassen, P.: Mapping the global value and distribution of coral reef tourism, Mar. Policy, 82, 104-113, https://doi.org/10.1016/j.marpol.2017.05.014, 2017.
Stead, S. M.: Rethinking marine resource governance for the United Nations sustainable development goals, Curr. Opin. Env. Sust., 34, 54-61, https://doi.org/10.1016/j.cosust.2018.12.001, 2018.

Stefanon, A.: Beachrock and paleogeography in the North Adriatic Sea, Rapport et Procés Verbaux des Reunion Commission Internationale pour l'Exploration Scientifique de la Mer Méditerranée, 20, 605-608, 1972.

Stolk, P., Markwell, K., and Jenkins, J. M.: Artificial Reefs as Recreational Scuba Diving Resources: A Critical Review of Research, J. Sust. Tour., 15, 331-350, https://doi.org/10.2167/jost651.0, 2007.

Tora, S., Sacchini, S., Listeš, E., Bogdanović, T., Di Lorenzo, A., Smajlović, M., Filipović, J. V., Tahirović, V., Šuković, D., Beljkas, B., Xinxo, A., Maçi, R., Colangeli, P., Di Giacinto, F., and Conte, A.: A geographical information system for the management of the aquaculture data in the Adriatic Sea-the Strengthening of Centres for Aquaculture Production and Safety surveillance in the Adriatic countries experience: Present capabilities, tools and functions, Geospatial Health, 12, 7, https://doi.org/10.4081/gh.2017.593, 2017.

Uyarra, M. C., Watkinson, A. R., and Côté, I. M.: Managing Dive Tourism for the Sustainable Use of Coral Reefs: Validating Diver Perceptions of Attractive Site Features, Environ. Manage., 43, 1 16, https://doi.org/10.1007/s00267-008-9198-z, 2009.

Vogt, H. P.: Economic benefits of tourism in the marine reserve of Apo Island, Philippines, Intercoast Network, 31, 13-14, 1998.

Wilhelmsson, D., Öhman, M. C., Ståhl, H., and Shlesinger, Y.: Artificial Reefs and Dive Tourism in Eilat, Israel, Ambio, 27, 764 766, 1998.

Wilkinson, M. D., Dumontier, M., Aalbersberg, I. J., Appleton, G., Axton, M., Baak, A., Blomberg, N., Boiten, J., Bonino da Silva Santos, L., Bourne, P. E., Bouwman, J., Brookes, A. J., Clark, T., Crosas, M., Dillo, I., Dumon, O., Edmunds, S., Evelo, C. T., Finkers, R., Gonzalez-Beltran, A., Gray, A. J. G., Groth, P., Goble, C., Grethe, J. S., Heringa, J., 't Hoen, P. A. C., Hooft, R., Kuhn, T., Kok, R., Kok, J., Lusher, S. J., Martone, M. E., Mons, A., Packer, A. L., Persson, B., Rocca-Serra, P., Roos, M., van Schaik, R., Sansone, S., Schultes, E., Sengstag, T., Slater, T., Strawn, G., Swertz, M. A., Thompson., M., van der Lei, J., van Mulligen, E., Velterop, J., Waagmeester, A., Wittenburg, P., Wolstencroft, K., Zhao, J., and Mons, B.: The FAIR Guiding Principles for scientific data management and stewardship, Sci. Data, 3, 160018, https://doi.org/10.1038/sdata.2016.18, 2016.

Zec, D., Fabi, G., and Soldati, M.: Deliverable 3.1.1. Definition of reefs' category, Work Package 3 - Mapping of Adriatic Reefs from different perspectives, Activity 1 - Reefs' classification in the cooperation area, ADRIREEF project, 2019. 